\title{
Use of chemical plant protection agents in the farms of Podkarpackie region
}

\author{
Zużycie chemicznych środków ochrony roślin \\ w wybranych gospodarstwach rolnych województwa podkarpackiego
}

\author{
Janusz Podleśny*, Karolina Smytkiewicz
}

\section{Summary}

The conducted studies analysed the pesticides consumption in the farms in Podkarpackie Voivodeship. These studies included farms diverse in terms of area, cropping structure and direction of production. Documentation material were the data obtained from questionnaire surveys conducted in 40 farms located in the different regions of Podkarpackie Voivodeship. Farms were selected in the purposeful manner in collaboration with Podkarpackie Agricultural Advisory Centre in Boguchwała. Conducted research showed a vast variety in the range of chemical plant protection. At all analysed farms the highest consumption was found for herbicides, much less for fungicides, and the least in the case of insecticides. A strong relationship was found between arable land area and the intensity of plant protection use, as well as obtained yield of crops. Large farms, with an area of over 30 ha, consumed almost $40 \%$ more active substance on 1 ha of arable land and obtained about $30 \%$ higher yields of crops than the smaller farms.

Key words: cropping structure, consumption of pesticides, active substance, yield

\section{Streszczenie}

W przeprowadzonych badaniach analizowano zużycie chemicznych środków ochrony roślin w gospodarstwach rolnych w województwie podkarpackim. Uwzględniono w nich gospodarstwa zróżnicowane pod względem areału, struktury zasiewów i kierunku produkcji. Materiał dokumentacyjny stanowiły dane uzyskane z badań ankietowych przeprowadzonych w 40 gospodarstwach usytuowanych w różnych rejonach województwa podkarpackiego. Wyboru gospodarstw dokonano w sposób celowy, przy współpracy z Podkarpackim Ośrodkiem Doradztwa Rolniczego w Boguchwale. Przeprowadzone badania wykazały duże zróżnicowanie w zakresie chemicznej ochrony roślin. We wszystkich analizowanych gospodarstwach rolnych zużywano najwięcej herbicydów, znacznie mniej fungicydów, a najmniej insektycydów. Stwierdzono silną zależność między powierzchnią użytków rolnych i intensywnością ochrony roślin a uzyskiwanym plonem ziemiopłodów. W gospodarstwach dużych, o powierzchni powyżej 30 ha zużywano prawie o $40 \%$ więcej substancji czynnej na 1 ha UR i uzyskiwano o około 30\% wyższe plony ziemiopłodów niż w gospodarstwach mniejszych.

Słowa kluczowe: struktura zasiewów, zużycie pestycydów, substancja czynna, plon

Instytut Uprawy Nawożenia i Gleboznawstwa - Państwowy Instytut Badawczy

Czartoryskich 8, 24-100 Puławy

*corresponding author: janusz.podlesny@iung.pulawy.pl 


\section{Wstęp / Introduction}

Jedną z podstawowych zasad współcześnie prowadzonej produkcji roślinnej jest racjonalne stosowanie środków ochrony roślin. Określają to liczne akty prawne, w tym zwłaszcza Dyrektywa Parlamentu Europejskiego i Rady 2009/128/WE (DUUE 2009) ustanawiająca ramy wspólnotowego działania na rzecz zrównoważonego stosowania pestycydów oraz Rozporządzenie Ministra Rolnictwa i Rozwoju Wsi (Dz.U. 2013) w sprawie wymagań integrowanej ochrony roślin. W rolnictwie polskim zachodzą bardzo szybkie zmiany prowadzące do specjalizacji i koncentracji produkcji (Krasowicz 2009; Ziętara 2014). Ich następstwem jest z jednej strony duża liczba gospodarstw prowadzących tylko produkcję roślinną, a z drugiej strony, gospodarstw nastawionych na intensywną produkcję zwierzęcą. Jednakże ten typ gospodarowania rodzi nowe problemy w zakresie sprostania wymaganiom stawianym rolnictwu $\mathrm{w}$ aspekcie jego oddziaływania na środowisko oraz produkcję ziemiopłodów o pożądanej jakości. Dane dotyczące zakresu stosowanej ochrony chemicznej dotyczą głównie zużycia środków chemicznych w uprawie nielicznych gatunków roślin uprawnych (GUS 2018a). Brakuje jednak szerszej analizy uwzględniającej powierzchnię gospodarstwa i kierunek prowadzonej produkcji rolnej. Wcześniej prowadzone badania obejmujące tylko niektóre regiony Polski (Bojarszczuk i Podleśny 2017) potwierdziły celowość tego typu prac. Jak wykazano bowiem, zakres prowadzonej ochrony roślin zależy w dużym stopniu od możliwości ekonomicznych gospodarstwa, uwarunkowanych między innymi poziomem prowadzonej produkcji rolnej (Jankowiak i wsp. 2012). Mając na uwadze duże zróżnicowanie regionalne i specyfikę polskiego rolnictwa (Krasowicz i Nieściór 2004; Baran 2014), analiza taka powinna być wykonana oddzielnie dla poszczególnych rejonów Polski. Dlatego w niniejszym opracowaniu podjęto próbę wykonania takiej analizy dla wybranych gospodarstw zlokalizowanych w województwie podkarpackim, które wyróżnia się dużym rozdrobnieniem gospodarstw oraz stosunkowo niską intensywnością produkcji rolnej.

Celem badań była ocena zużycia chemicznych środków ochrony roślin w zależności od wielkości powierzchni gospodarstwa rolnego, stosowanej struktury zasiewów oraz poziomu uzyskiwanych plonów.

\section{Materiały i metody / Materials and methods}

Materiał dokumentacyjny stanowiły dane uzyskane z badań ankietowych przeprowadzonych w 40 gospodarstwach usytuowanych w różnych rejonach województwa podkarpackiego (rys. 1).

Wyboru gospodarstw dokonano w sposób celowy, przy współpracy z Podkarpackim Ośrodkiem Doradztwa Rol-

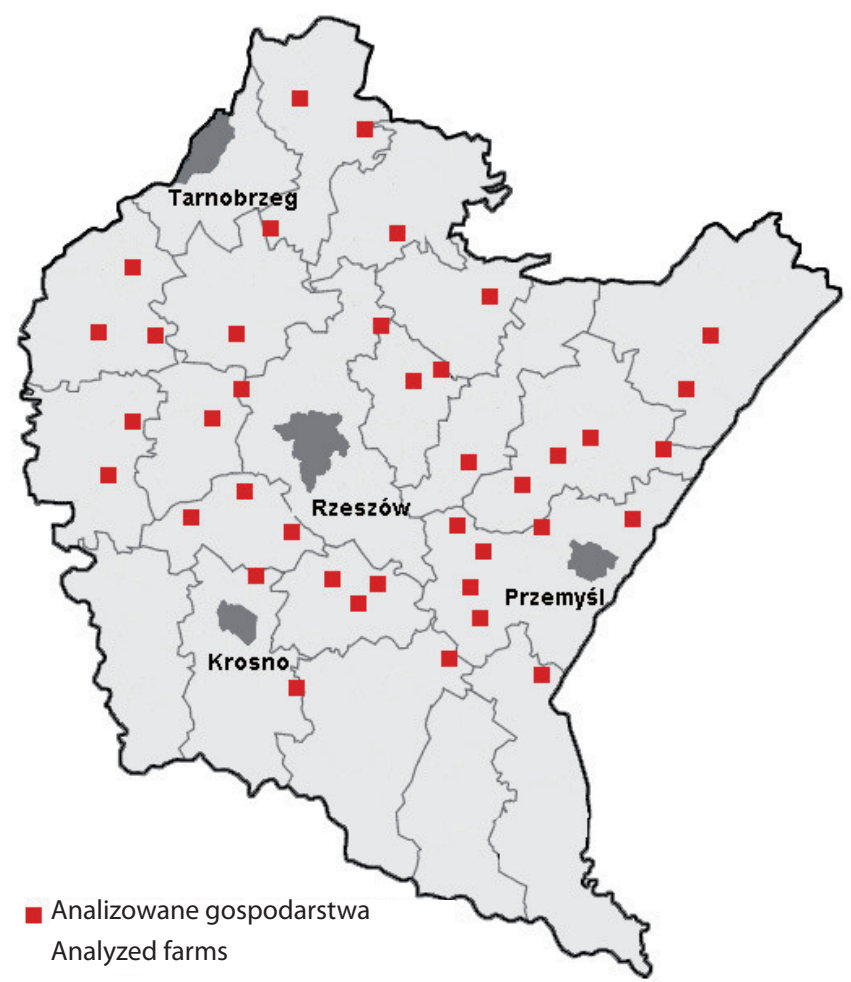

Rys. 1. Lokalizacja analizowanych gospodarstw rolnych na terenie województwa podkarpackiego

Fig. 1. Location of analyzed farms in the area of the Podkarpackie voivedeship

niczego w Boguchwale. Polegało to na wyborze obiektów $\mathrm{z}$ interesującej nas populacji na podstawie precyzyjnie określonych kryteriów zapewniających kontrolę zarówno homogeniczności, jak i zróżnicowania próby. Starano się, aby w każdym przedziale wielkości powierzchni była taka sama liczba gospodarstw o zbliżonej intensywności i różnych kierunkach prowadzonej produkcji rolnej. W celu zapewnienia dużej wiarygodności danych, uzyskane rezultaty były wielokrotnie weryfikowane najpierw na poziomie gospodarstwa, a później także podczas ich szczegółowego opracowywania. Pomimo pewnych utrudnień wynikających z ograniczonej możliwości uogólnienia próby, taki dobór gospodarstw jest często stosowany w tego typu badaniach rolniczych, ponieważ pozwala na poznanie różnych zależności występujących w badanej zbiorowości (Kołoszko-Chomentowska 2013). Ankiety zostały opracowane w Zakładzie Uprawy Roślin Pastewnych Instytutu Uprawy Nawożenia i Gleboznawstwa - Państwowego Instytutu Badawczego w Puławach, natomiast dane nanieśli pracownicy Podkarpackiego Ośrodka Doradztwa Rolniczego w Boguchwale. W każdej ankiecie zamieszczono szczegółowe pytania dotyczące ogólnych informacji o gospodarstwie, struktury zasiewów, wyposażenia w maszyny i urządzenia oraz szczegółowe dane dotyczące technologii produkcji roślinnej, W szczególności stosowanej ochrony roślin. Utworzono 5 grup obszarowych gospodarstw: 10-20, 21-30, 31-50, 
51-100 i powyżej 100 ha. Przyjęto podział na przedziały stosowane wcześniej w tego typu badaniach.

Analizowano następujące wskaźniki związane z ochroną roślin: strukturę zasiewów, strukturę zużycia środków ochrony roślin, ilość zużytej substancji czynnej na 1 ha użytków rolnych (UR) oraz plony podstawowych ziemiopłodów.

\section{Wyniki i dyskusja / Results and discussion}

Analizowane gospodarstwa prowadziły działalność rolniczą na powierzchni 2726 ha UR, w tym grunty orne zajmowały 2390 ha, czyli 87,7\% UR. W gospodarstwach dominowały gleby dobrej jakości, bowiem grunty orne (GO) należące do klas I-IVa, stanowiły 60,1\% ogólnej powierzchni GO. Natomiast gleby słabszej (IVb) i najsłabszej jakości (V i VI) odpowiednio: 19,6; 18,4 i 1,9\% GO.

Przeciętna wielkość gospodarstwa wynosiła 68,1 ha. Na 1 zatrudnionego $\mathrm{w}$ gospodarstwie przypadało 28,1 ha UR. Przeciętna obsada zwierząt dla gospodarstw prowadzących produkcję zwierzęcą wynosiła 0,84 DJP (Duża Jednostka Przeliczeniowa)/ha UR.

Właściciele objętych analizą gospodarstw posiadali najczęściej wykształcenie średnie (52,5\%) lub zawodowe (32,5\%), a 15,0\% z nich miało ukończone studia wyższe. Oznacza to, że znaczny odsetek absolwentów uczelni rolniczych to właściciele lub następcy przejmujący gospodarstwa od rodziców. Rolnicy z wykształceniem wyższym lub średnim posiadali na ogół gospodarstwa o większej powierzchni (średnio 73,9 ha UR), a pozostali rolnicy - gospodarstwa mniejsze (średnio 41,8 ha UR). Natomiast 37,5\% analizowanych gospodarstw nie miało następcy, co może wskazywać na zmniejszające się zainteresowanie ludzi młodych pracą na wsi. Zdaniem Klepackiego i Gołębiewskiej (2004) wskaźnik wykształcenia ma bardzo duże znaczenie, bowiem decyduje w dużym stopniu m.in. o intensywności prowadzonej produkcji rolniczej, wielkości uzyskiwanych dochodów oraz zakresie inwestycji prowadzonych w gospodarstwie. Również z badań Kołoszko-Chomentowskiej (2013) wynika, że dochód z rodzinnego gospodarstwa rolnego jest silnie skorelowany z wykształceniem kierownika tego gospodarstwa.

W strukturze zasiewów dominowały zboża, którymi obsiewano przeciętnie 61,6\% gruntów ornych (rys. 2). Wprawdzie wskaźnik ten kształtuje się poniżej średniej dla kraju $(72,1 \%)$ i dla województwa podkarpackiego $(73,0 \%)$ (GUS 2019), ale jego wartość była bardzo zróżnicowana w poszczególnych rejonach i analizowanych gospodarstwach. Największy udział zbóż w strukturze zasiewów odnotowano w grupie gospodarstw o powierzchni 10-50 ha (74,6\%), a najmniejszy w gospodarstwach o powierzchni 51-100 ha $(53,1 \%)$ i powyżej 100 ha $(54,6 \%)$. Spośród zbóż dominowała uprawa pszenicy ozimej i pszenżyta ozimego, natomiast spośród innych roślin - uprawa kukurydzy i rzepaku ozimego. Ziemniak i burak cukrowy stanowiły niewielki odsetek w strukturze zasiewów, zajmując odpowiednio: 1,03 i 3,61\% gruntów ornych. Poprawne następstwo roślin w płodozmianie ma bardzo duże znaczenie w ograniczaniu chorób i szkodników (Smagacz 2007; Małecka-Jankowiak i wsp. 2015). Uproszczone zmianowania sprzyjają namnażaniu agrofagów, zwłaszcza patogenów roślin (Korbas i wsp. 2008). Zgodnie z wymaganiami integrowanej ochrony, udział zbóż w płodozmianie nie powinien przekraczać 66\% struktury zasiewów (Korbas i Mrówczyński 2014). Ponadto zboża ozime powinny być przedzielone przynajmniej

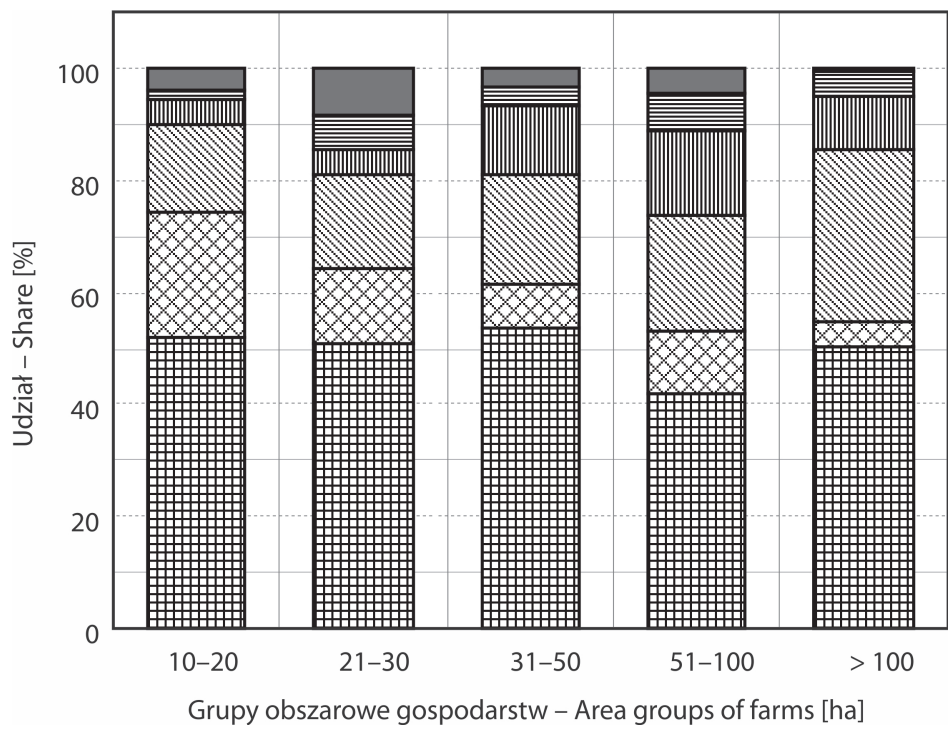

Rys. 2. Struktura zasiewów w zależności od wielkości gospodarstwa

Fig. 2. Cropping system in dependence on farm area
囲 Zboża ozime - Winter cereals

Z Zboża jare - Spring cereals

$\$$ Rzepak - Oilseed rape

血 Kukurydza - Maize

Okopowe-Root crops

Inne - Others 
jedną uprawą niebędącą gospodarzem głównych chorób tej grupy roślin. Najczęściej rośliną tą jest rzepak ozimy (Jajor i wsp. 2012), rzadziej rośliny strączkowe, bowiem ich udział w strukturze zasiewów jest ciągle mały (GUS 2019). Jednak częsta uprawa rzepaku na tym samym polu może zwiększać nagromadzenie patogenów, w tym głównie powodujących kiłę kapusty (Mrówczyński 2003). Z danych literaturowych wynika, że maksymalny udział rzepaku w strukturze zasiewów nie powinien być większy niż 25\% (Jajor i wsp. 2019). $\mathrm{W}$ analizowanych gospodarstwach rolnych udział rzepaku w strukturze zasiewów wynosił średnio 20,8\%. Przy czym dopuszczalna granica $25 \%$ była przekroczona tylko w gospodarstwach o powierzchni powyżej 100 ha, gdzie udział rzepaku wynosił 30,8\%. Natomiast w gospodarstwach do 100 ha udział ten zawierał się w granicach 15-20\% i zwiększał się wraz ze wzrostem obszaru gospodarstwa.

W analizowanych gospodarstwach, stosowano zróżnicowaną liczbę zabiegów ochrony chemicznej, w uprawie poszczególnych gatunków roślin (rys. 3). Najwięcej zabiegów ochrony wykonywano w uprawie roślin okopowych (zwłaszcza buraka cukrowego), zbóż ozimych i rzepaku, nieco mniej w uprawie zbóż jarych i kukurydzy, a najmniej w uprawie pozostałych gatunków roślin, do których należały głównie: gryka, rośliny strączkowe oraz mieszanki zbożowe i zbożowo-strączkowe. Wskaźnik ten odzwierciedla intensywność prowadzonej ochrony chemicznej w danym gospodarstwie i może wskazywać także na zwiększone obciążenie środowiska skażeniami miejscowymi związanymi z aplikacją środków ochrony roślin (sporządzanie cieczy roboczej, mycie opryskiwacza, zabezpieczenie pozostałej cieczy roboczej itp.).

Łącznie w uprawie wszystkich gatunków, najwięcej zabiegów wykonywano w gospodarstwach o powierzchni powyżej 100 ha $(18,3)$, nieco mniej w gospodarstwach należących do grup obszarowych: 10-20 i 31-50 ha (odpowiednio: 15,1 i 15,5), a najmniej w grupie gospodarstw 21-30 ha $(9,9)$. Decydowała o tym w dużej mierze struktura zasiewów, w tym zwłaszcza udział roślin wymagających intensywnej ochrony chemicznej.

Najczęściej stosowanym i miarodajnym wskaźnikiem oceny intensywności ochrony chemicznej roślin jest ilość zużytej substancji czynnej (s.cz.) na 1 ha użytków rolnych (Korbas i Mrówczyński 2014; Mickiewicz i Mickiewicz 2014). Wprowadzanie coraz częściej środków chemicznych nowej generacji znacznie zmienia wartość tego wskaźnika, ponieważ preparaty te są stosowane zazwyczaj w mniejszych dawkach. Przykładem tego może być kukurydza, w uprawie której stosowano zazwyczaj jeden zabieg w celu zwalczania chwastów, ale ilość zużytej s.cz. wahała się w zależności od gospodarstwa w granicach od 0,49 do $1,14 \mathrm{~kg} / \mathrm{ha}$.

Z przeprowadzonej analizy wynika, że najwięcej substancji czynnej na 1 ha stosowano w gospodarstwach o powierzchni powyżej 31-50 ha i w gospodarstwach powyżej 100 ha (odpowiednio: 1,27 i 1,21 kg s.cz./ha), nieco mniej w grupie gospodarstw $51-100$ ha $(1,06 \mathrm{~kg}$ s.cz./ha), a najmniej w gospodarstwach 10-20 i 21-30 ha (odpowiednio: 0,92 i $0,86 \mathrm{~kg} \mathrm{s.cz./ha)} \mathrm{(rys.} \mathrm{4).}$

Również w badaniach Jankowiaka i wsp. (2012) wykazano, że intensywność ochrony chemicznej zależy od struktury obszarowej gospodarstw, przy czym większość gospodarstw małych stosuje najczęściej 1-2, natomiast gospodarstwa duże 3-5 rodzajów środków ochrony roślin.

Z przeprowadzonej analizy wynika, że najwięcej substancji czynnej na 1 ha gruntów ornych zużywano w uprawie zbóż ozimych, rzepaku i roślin okopowych (średnio $1,28 \mathrm{~kg} / \mathrm{ha})$, znacznie mniej w uprawie kukurydzy $(0,82 \mathrm{~kg} / \mathrm{ha})$, a najmniej w uprawie pozostałych gatunków roślin $(0,44 \mathrm{~kg} / \mathrm{ha})$ (rys. 4). O wartości tego wskaźnika decydowała liczba wykonywanych zabiegów oraz zastosowana dawka preparatu. W niektórych gospodarstwach ilość

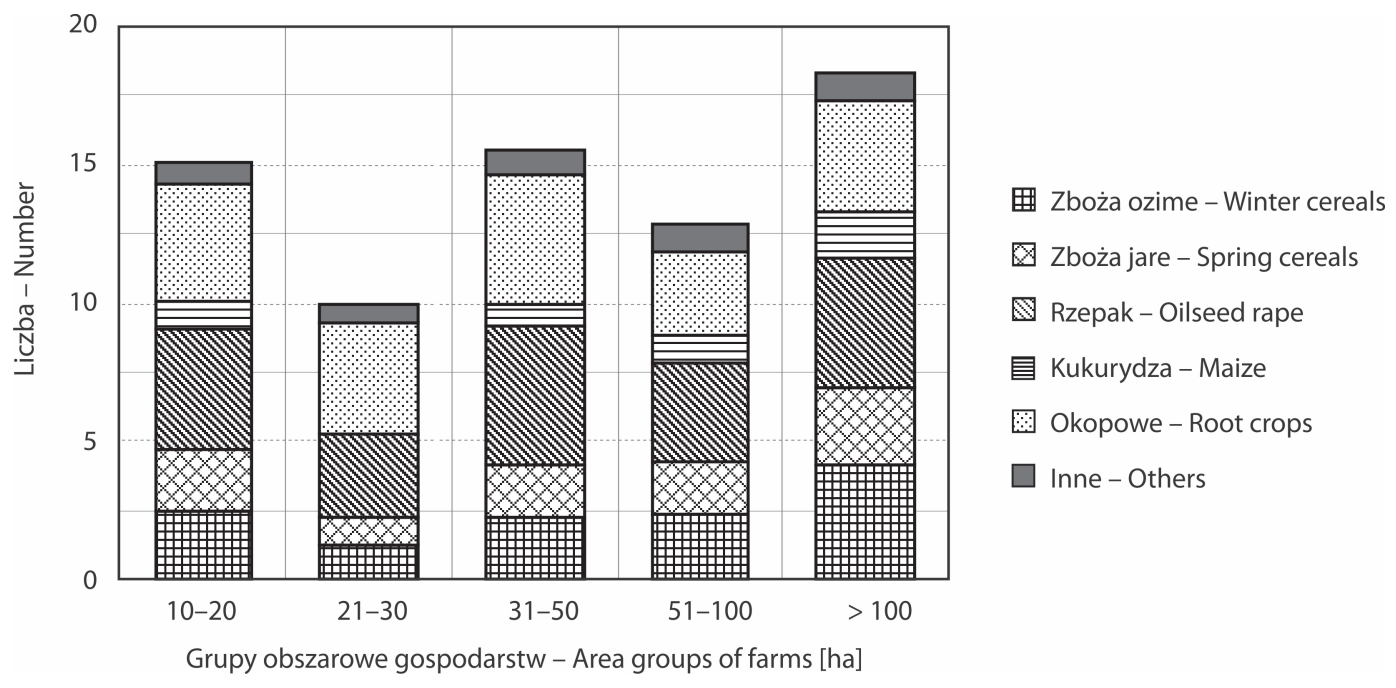

Rys. 3. Przeciętna liczba zabiegów chemicznych wykonywanych w uprawie wybranych gatunków roślin uprawnych

Fig. 3. The average number of chemical treatments performing in cultivation of selected crops species 


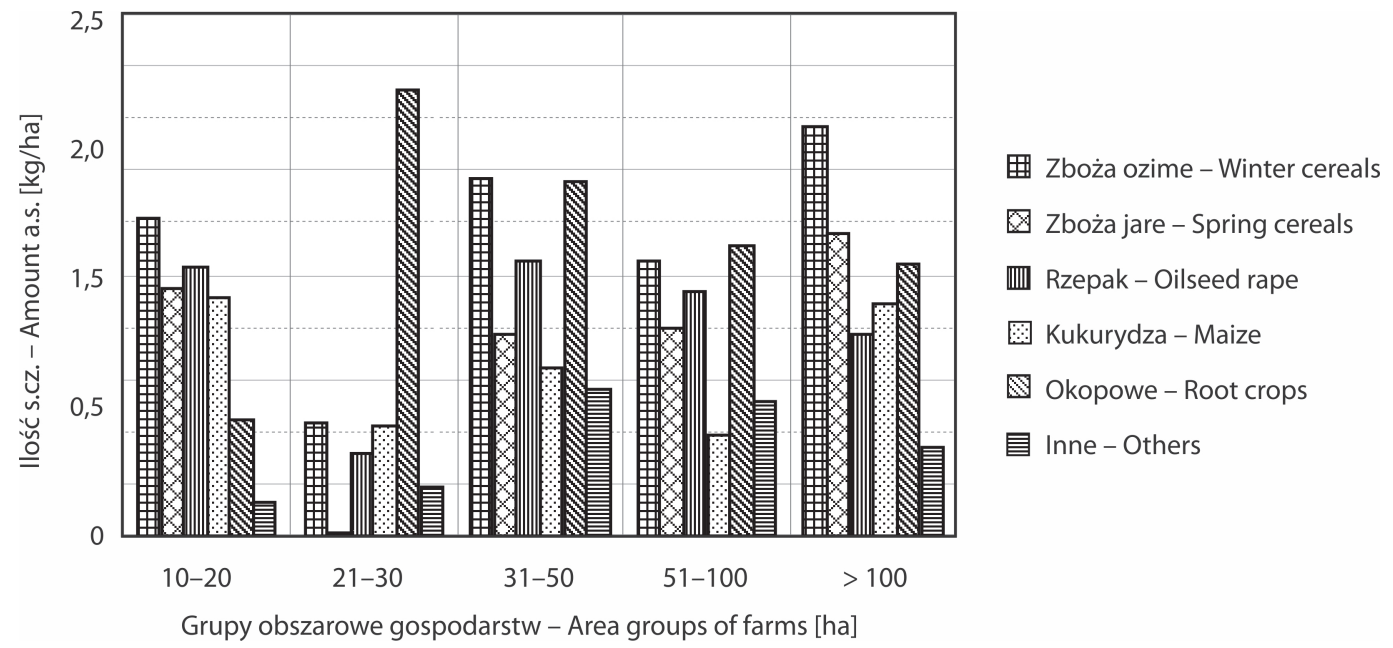

Rys. 4. Ilość substancji czynnej zużytej na 1 ha gruntów ornych

Fig. 4. The amount of active substance used on 1 ha of arable lands

zużytej s.cz. była mniejsza pomimo stosowania takiej samej liczby zabiegów, co wskazuje na stosowanie innych preparatów, bądź mniejszych ich dawek.

Zużycie środków ochrony roślin w analizowanych gospodarstwach na ogół przekraczało średnią dla kraju. Na przykład w uprawie pszenicy ozimej wynosiło 1,91 kg s.cz./ha, przy średniej krajowej na poziomie 1,32 kg s.cz./ha (GUS 2018a). Można przypuszczać, że różnica pomiędzy wynikami uzyskanymi w analizowanych gospodarstwach i danymi dla Polski wynika z faktu, że analizą objęto gospodarstwa, które charakteryzowały się dobrą perspektywą dalszego rozwoju, o wysokim poziomie prowadzonej produkcji roślinnej.

We wszystkich gospodarstwach rolnych zużywano najwięcej herbicydów, znacznie mniej fungicydów, a najmniej insektycydów (rys. 5). Podobną strukturę zużycia środków ochrony roślin potwierdza także ilość ich sprzedaży w Polsce. W roku 2017 sprzedano w naszym kraju 25075 t środków ochrony roślin, z tego herbicydy, fungicydy, insektycydy oraz pozostałe preparaty stanowiły odpowiednio: 54,5; 27,6; 7,3 i 10,7\% (GUS 2018a).

Najwięcej substancji czynnej herbicydów zużywano w uprawie roślin okopowych, w tym zwłaszcza buraka cukrowego, nieco mniej w uprawie kukurydzy i rzepaku, a najmniej w uprawie zbóż ozimych i jarych (rys. 6). W gospodarstwach mniejszych (do 30 ha UR) przeciętne zużycie tych substancji było mniejsze i wynosiło średnio dla wszystkich upraw $0,44 \mathrm{~kg}$ s.cz./ha, natomiast w gospodarstwach większych (powyżej 30 ha) - 0,66 kg s.cz./ha.

Natomiast w odniesieniu do fungicydów największe ilości tych preparatów zużywano w uprawie zbóż ozimych, okopowych i rzepaku, a najmniej w uprawie kukurydzy i roślin określanych jako „pozostałe” (rys. 7).

We wszystkich grupach gospodarstw zużywano na ogół podobną ilość substancji czynnej fungicydów na 1 ha UR (średnio 0,36 kg s.cz./ha). Nieznacznie większe zużycie tych substancji stwierdzono w grupie gospodarstw o powierzchni $30-50$ ha $(0,41 \mathrm{~kg} \mathrm{s.cz} . / \mathrm{ha})$.

Najwięcej insektycydów stosowano w uprawie rzepaku i roślin okopowych (średnio $130 \mathrm{~g}$ s.cz./ha), a najmniej w uprawie zbóż jarych i kukurydzy, odpowiednio: 2,6 i 7,2 g s.cz./ha (rys. 8). We wszystkich grupach gospodarstw zużywano podobną ilość substancji czynnej insektycydów na 1 ha UR (średnio 48,4 g).

Na uwagę zasługuje zużycie s.cz. insektycydów w ochronie rzepaku. W pierwszych trzech grupach gospodarstw zużycie to zwiększało się wraz ze wzrostem powierzchni gospodarstw, natomiast w grupie skupiającej największe obszarowo gospodarstwa było najmniejsze. Wynikało to prawdopodobnie z faktu, że w grupie gospodarstw o powierzchni większej niż 100 ha decyzję o stosowaniu zabiegów ochrony roślin podejmowano często na podstawie komputerowego systemu wspomagania decyzji. Natomiast w pozostałych gospodarstwach na podstawie własnych obserwacji lub niekiedy doradcy rolniczego.

Zakres zastosowanej ochrony chemicznej roślin miał odzwierciedlenie w wielkości uzyskiwanych plonów. W gospodarstwach o powierzchni do 30 ha plon ziarna zbóż ozimych i jarych wynosił średnio 4,53 t/ha (rys. 9), natomiast w grupie gospodarstw większych (powyżej 30 ha) był o około 1,53 t wyższy i kształtował się na poziomie 6,06 t/ha. W roku 2017 plon ziarna zbóż w województwie podkarpackim kształtował się na poziomie 3,91 t/ha (GUS 2018b), natomiast $w$ analizowanych gospodarstwach był wyższy i wynosił 5,29 t/ha. Wraz ze zwiększeniem powierzchni gospodarstwa zwiększał się na ogół plon zbóż i rzepaku (rys. 8). Najbardziej zbliżony do uzyskiwanego średnio w kraju (4,2 t/ha) (GUS 2018b), był plon zbóż uzyskany w grupie gospodarstw o powierzchni 21-30 ha (4,48 t/ha). 


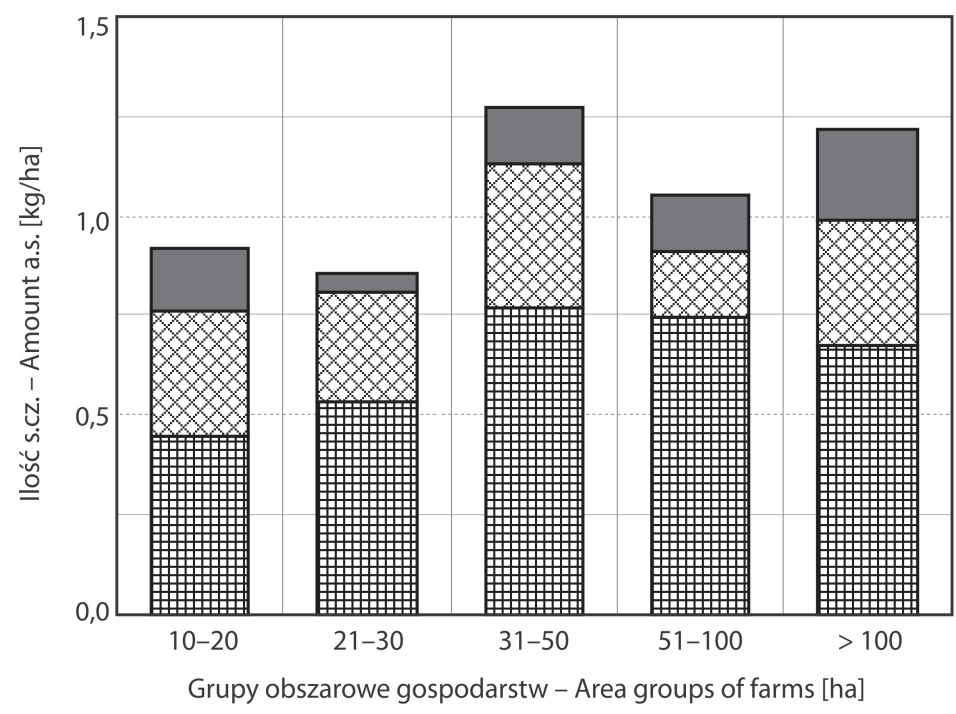

囲 Herbicydy - Herbicides

$\nabla$ Fungicydy - Fungicides

Insektycydy - Insecticides

Rys. 5. Struktura zużycia środków ochrony roślin w zależności od wielkości gospodarstwa

Fig. 5. Structure of pesticides consumption in dependence on farm area

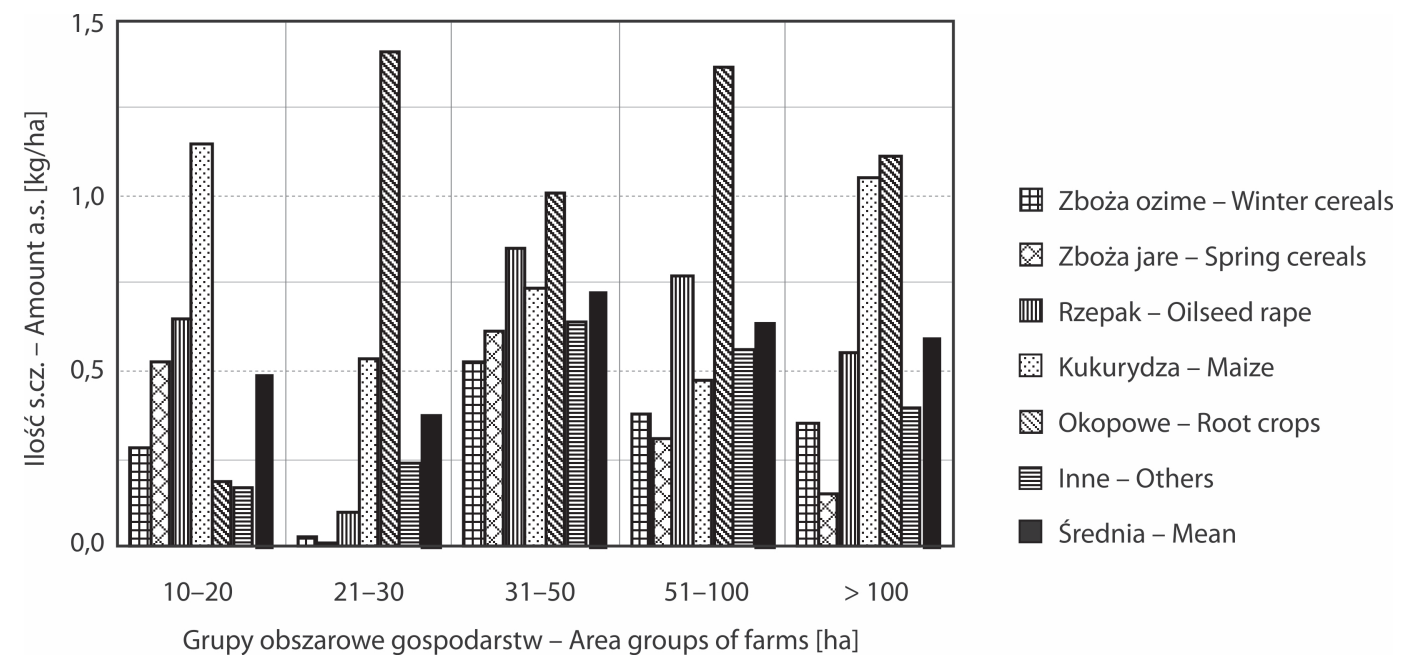

Rys. 6. Struktura zużycia herbicydów w uprawie wybranych roślin

Fig. 6. Structure of herbicides consumption in the cultivation of selected plants

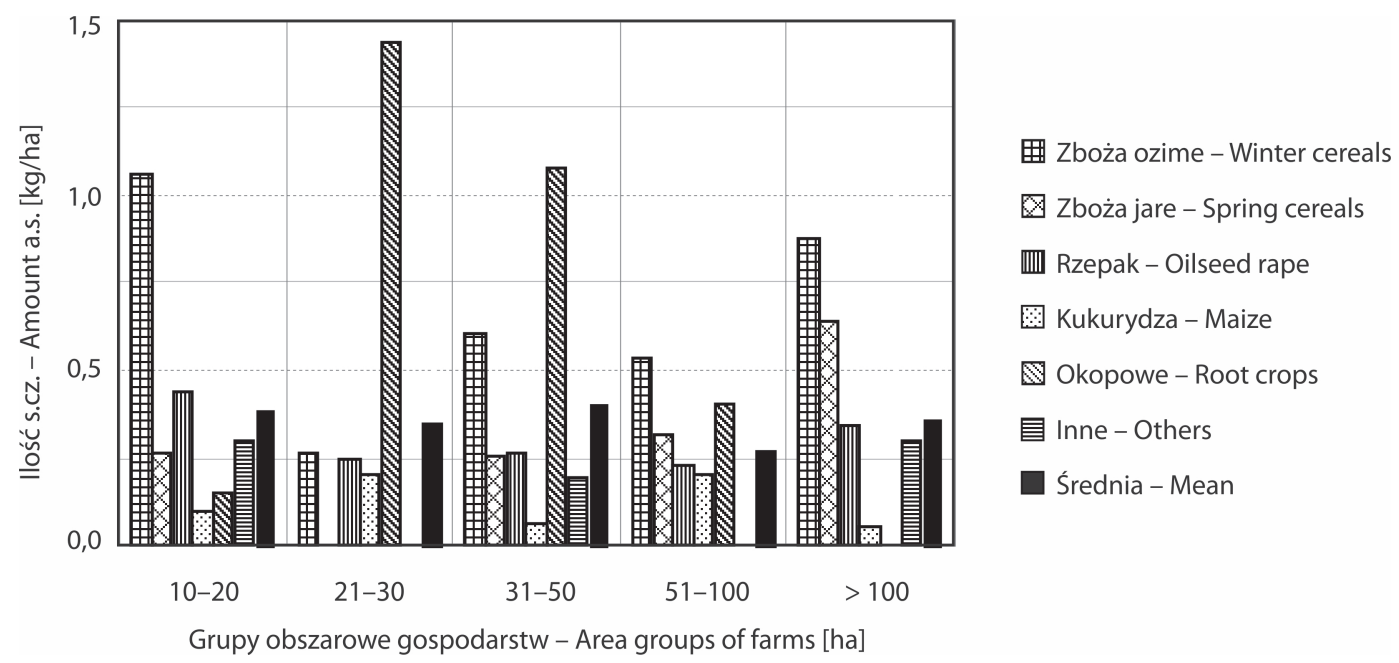

Rys. 7. Struktura zużycia fungicydów w uprawie wybranych roślin

Fig. 7. Structure of fungicides consumption in the cultivation of selected plants 


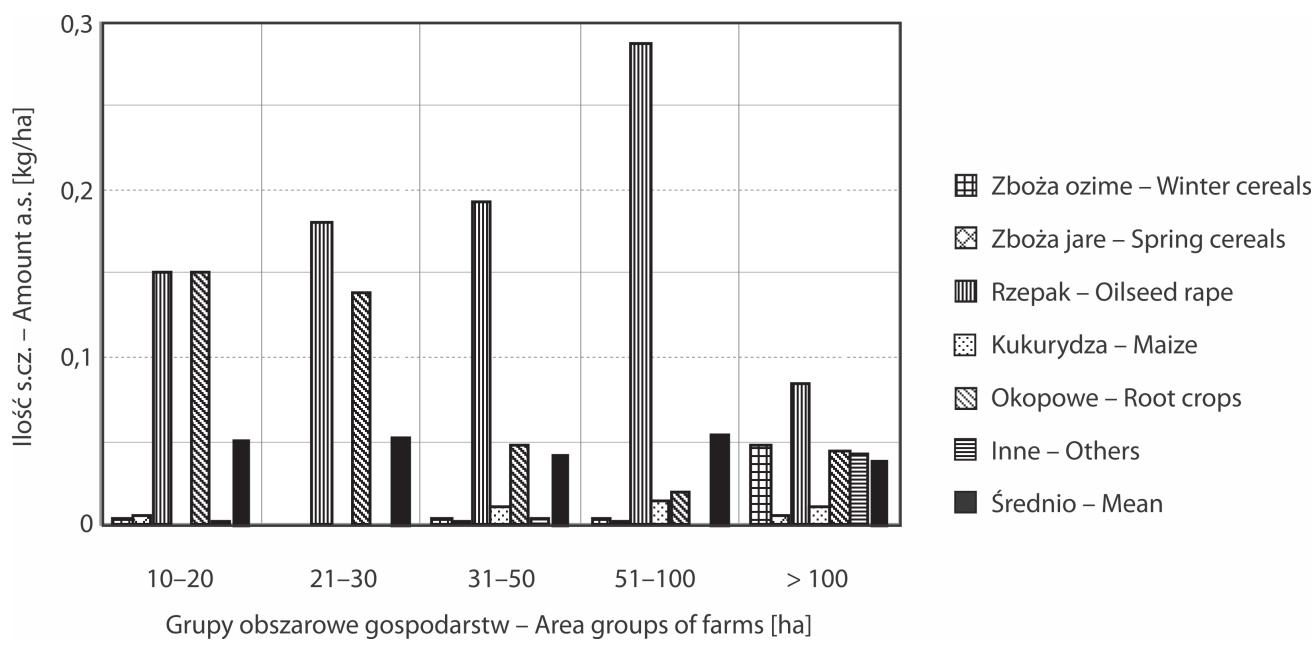

Rys. 8. Struktura zużycia insektycydów w uprawie wybranych roślin

Fig. 8. Structure of insecticides consumption in the cultivation of selected plants

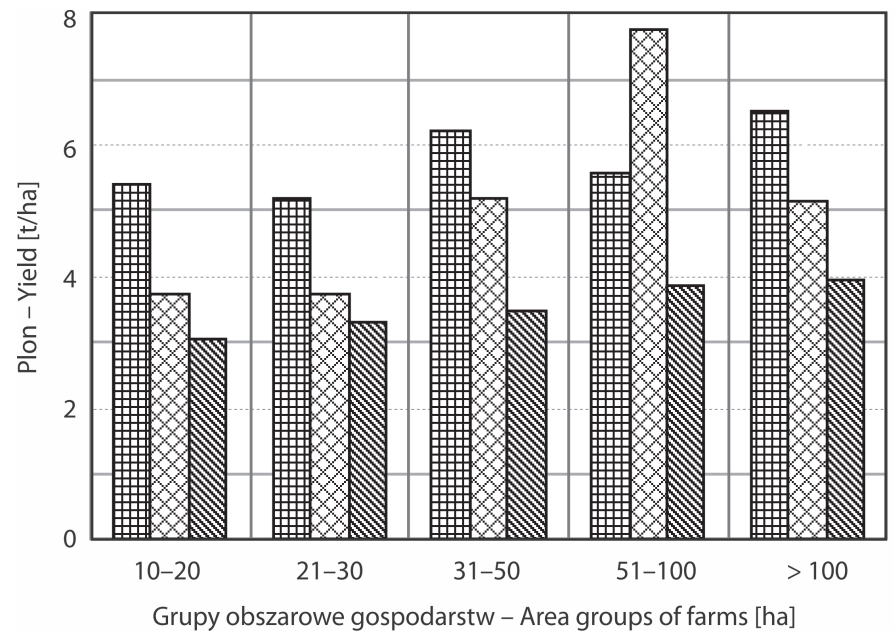

团 Zboża ozime - Winter cereals

Zboża jare - Spring cereals

$\mathbb{Q}$ Rzepak - Oilseed rape

Rys. 9. Plon roślin najczęściej uprawianych w analizowanych gospodarstwach rolnych Fig. 9. The yield of most frequently cultivated plants in the analyzed farms

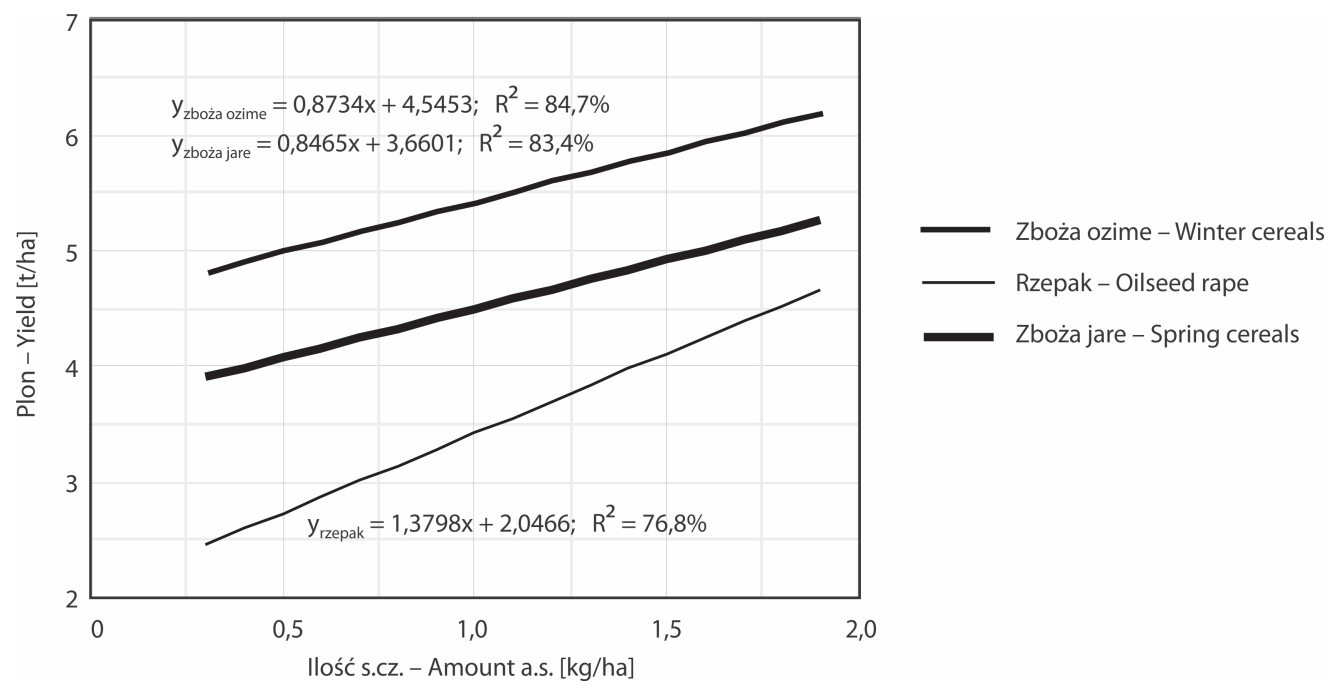

Rys. 10. Zależność plonu roślin najczęściej uprawianych w analizowanych gospodarstwach rolnych od ilości substancji czynnej zużywanej na 1 ha gruntów ornych

Fig. 10. Dependency of yield of most frequently cultivated plants in analyzed farms on the amount of active substances used on 1 ha of arable lands 
Zależność plonu wybranych, najczęściej uprawianych gatunków roślin od ilości zastosowanej substancji czynnej przedstawiono w postaci regresji (rys. 10). Stwierdzono dodatnią korelację między ilością stosowanej substancji czynnej a plonem ziemiopłodów. Z przebiegu prostych wynika, że efekt mierzony wielkością plonu był nieznacznie zróżnicowany w odniesieniu do analizowanych gatunków roślin, o czym świadczy współczynnik kierunkowy prostej, określający ich nachylenie względem osi „x”. Zwiększenie ilości substancji czynnej o $1 \mathrm{~kg}$ (z 0,5 do $1,5 \mathrm{~kg} / \mathrm{ha}$ ) powodowało przyrost plonu zbóż ozimych i jarych oraz rzepaku odpowiednio o: 0,87; 0,85 i 1,38 t/ha.

\section{Wnioski / Conclusions}

1. Wykazano duże zróżnicowanie w stosowaniu chemicznej ochrony roślin w zależności od powierzchni gospodarstwa i struktury zasiewów. Najwięcej substancji czynnej na 1 ha gruntów ornych stosowano w gospodarstwach o powierzchni $31-50$ ha i w gospodarstwach powyżej 100 ha, mniejsze w grupie gospodarstw 51-100 ha, a najmniejsze w gospodarstwach 10-20 i 21-30 ha.

2. Niezależnie od wielkości gospodarstwa, dominowało zużycie herbicydów - znacznie mniej zużywano fungicydów, a najmniej insektycydów.
3. Stwierdzono silną zależność między powierzchnią UR a intensywnością stosowanej ochrony roślin. W gospodarstwach o powierzchni powyżej 30 ha zużywano prawie o 40\% więcej substancji czynnej na 1 ha UR i uzyskiwano o około 30\% wyższe plony ziemiopłodów niż w gospodarstwach mniejszych.

4. Stwierdzono wysoką korelację między ilością stosowanej substancji czynnej a plonem ziemiopłodów. Wykazano, że wraz ze wzrostem ilości substancji czynnej następował przyrost plonu ziemiopłodów. Uzasadnia to racjonalne, zgodne z zasadami agrotechniki zwiększanie ilości substancji czynnej na 1 ha $\mathrm{w}$ celu podniesienia plonu roślin.

5. Uzyskane wyniki dają bardzo dobry pogląd na sposób ochrony roślin w gospodarstwach województwa podkarpackiego oraz stanowią bazę danych przydatną do wykorzystania w innych analizach z zakresu produkcji roślinnej.

Praca wykonana w ramach realizacji zadania 2.3 Programu Wieloletniego Instytutu Uprawy Nawożenia i Gleboznawstwa - Państwowego Instytutu Badawczego w Puławach pt. „Wspieranie działań w zakresie ochrony i racjonalnego wykorzystania rolniczej przestrzeni produkcyjnej w Polsce oraz kształtowania jakości surowców roślinnych na lata 2016-2020".

\section{Literatura / References}

Baran J. 2014. Regionalne zróżnicowanie efektywności rolnictwa w Polsce. [Diversification of efficiency of agriculture in Poland]. Roczniki Naukowe Ekonomii Rolnictwa i Rozwoju Obszarów Wiejskich 101 (2): 20-28.

Bojarszczuk J., Podleśny J. 2017. Koszty ochrony roślin w wybranych gospodarstwach rolnych województwa lubelskiego. [Plant protection costs in the selected farms in Lublin Voivodeship]. Progress in Plant Protection 57 (4): 266-271. DOI: 10.14199/ppp-2017-041

DUUE 2009. Dyrektywa Parlamentu Europejskiego i Rady 2009/128/WE z dnia 21 października 2009 r. ustanawiająca ramy wspólnotowego działania na rzecz zrównoważonego stosowania pestycydów. Dziennik Urzędowy Unii Europejskiej L 309/71 z 24.11.2009: 71-86.

Dz.U. 2013. Rozporzadzenie Ministra Rolnictwa i Rozwoju Wsi z dnia 18 kwietnia 2013 r. w sprawie wymagań integrowanej ochrony roślin. Dz.U. z 26.04.2013 r., poz. 505: 1-2.

GUS 2018a. Środki produkcji w rolnictwie w roku gospodarczym 2017/2018. Główny Urząd Statystyczny, Warszawa.

GUS 2018b. Produkcja upraw rolnych i ogrodniczych w 2017 r. Główny Urząd Statystyczny, Warszawa.

GUS 2019. Użytkowanie gruntów i powierzchnia zasiewów w 2018 roku. Główny Urząd Statystyczny, Warszawa.

Jajor E., Horoszkiewicz-Janka J., Danielewicz J., Korbas M. 2012. Wpływ zmianowania i fungicydów na ograniczanie występowania chorób rzepaku ozimego. [Influence of crop rotation and fungicides on occurrence limitation of winter oilseed rape diseases]. Progress in Plant Protection/Postepy w Ochronie Roślin 52 (4): 1005-1010. DOI: 10.14199/ppp-2012-173

Jajor E., Strażyński P., Mrówczyński M. (red.). 2019. Metodyka integrowanej ochrony rzepaku ozimego oraz jarego dla doradców. Instytut Ochrony Roślin - Państwowy Instytut Badawczy, Poznań, 316 ss.

Jankowiak J., Bieńkowski J., Holka M., Dąbrowicz R. 2012. Zużycie środków ochrony roślin na tle zmian w produkcji rolniczej. [The consumption of plant protection products in the background of changes in agricultural production]. Progress in Plant Protection/ Postępy w Ochronie Roślin 52 (4): 1177-1183. DOI: 10.14199/ppp-2012-202

Klepacki B., Gołębiewska B. 2004. Wykształcenie rolników jako forma różnicująca sytuację gospodarstw rolnych. s. 457-465. W: Kapitał ludzki i intelektualny jako czynnik wzrostu gospodarczego i ograniczenia nierówności społecznych (M.G. Woźniak, red.). Wydawnictwo Mittel, Rzeszów.

Kołoszko-Chomentowska Z. 2013. Przyrodnicze i organizacyjno-ekonomiczne uwarunkowania rozwoju rodzinnych gospodarstw rolnych w województwie podlaskim. Monografie i Rozprawy Naukowe 41. Instytut Uprawy Nawożenia i Gleboznawstwa - Państwowy Instytut Badawczy, Puławy, 135 ss.

Korbas M., Horoszkiewicz-Janka J., Jajor E. 2008. Uproszczone systemy uprawy a występowanie sprawców chorób. [Simplified systems of soil management in relation to the occurrence of disease casual agents]. Progress in Plant Protection/Postepy w Ochronie Roślin 48 (4): 1431-1438. 
Korbas M., Mrówczyński M. (red.). 2014. Metodyka integrowanej produkcji pszenicy ozimej i jarej. Państwowa Inspekcja Ochrony Roślin i Nasiennictwa, Warszawa, 90 ss.

Krasowicz S. 2009. Regionalne zróżnicowanie zmian w rolnictwie polskim. Studia i Raporty IUNG-PIB 15: 9-36.

Krasowicz S., Nieściór E. 2004. Regionalne zróżnicowanie intensywności organizacji produkcji rolnej w Polsce. [Regional differences in the intensity of agricultural production organisation in Poland]. Acta Agraria et Silvestria 43 (1): 131-141.

Małecka-Jankowiak I., Blecharczyk A., Sawinska Z., Piechota T., Waniorek B. 2015. Wpływ następstwa roślin i systemu uprawy roli na zachwaszczenie pszenicy ozimej. [Impact of crop sequence and tillage system on weed infestation of winter wheat]. Fragmenta Agronomica 32 (3): 54-63.

Mickiewicz A., Mickiewicz B. 2014. Stosowanie środków produkcji w świetle nowych zasad integrowania ochrony roślin. [Use of production means in light of new rules of integrated plant protection]. Roczniki Naukowe Stowarzyszenia Ekonomistów Rolnictwa i Agrobiznesu 16 (5): 160-168. DOI: 10.22004/ag.econ.205242

Mrówczyński M. 2003. Studium nad doskonaleniem ochrony rzepaku ozimego przed szkodnikami. Rozprawy Naukowe Instytutu Ochrony Roślin 10,61 ss.

Smagacz J. 2007. Rola zmianowania w integrowanej produkcji roślinnej. s. 147-154. W: Integrowana produkcja roślinna. Zagadnienia wybrane (J. Podleśny, red.). Instytut Uprawy Nawożenia i Gleboznawstwa - Państwowy Instytut Badawczy, Puławy, 212 ss.

Ziętara W. 2014. Koncentracja i specjalizacja gospodarstw rolniczych w procesie integracji z Unią Europejską. [Concentration and specialisation of agricultural holdings in the process of European Union integration]. Zeszyty Naukowe Szkoły Głównej Gospodarstwa Wiejskiego w Warszawie, Problemy Rolnictwa Światowego 14 (1): 157-169. 